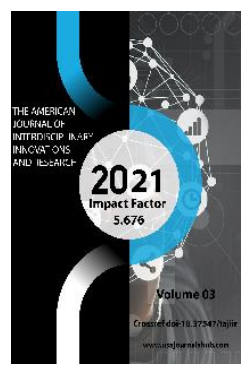

\title{
Effective Use Of Fixed Assets In The Development Of The Digital Economy
}

\author{
Samiddin Nizamovich Tashnazarov \\ Samarkand Institute Of Economics And Service, Uzbekistan \\ Nematova Dilnoza Azamatovna \\ Samarkand Institute Of Economics And Service, Uzbekistan
}

Copyright: Original content from this work may be used under the terms of the creative commons attributes 4.0 licence.

\section{ABSTRACT}

This article provides recommendations on the development of the digital economy, its implementation in all spheres of life, as well as its fruitful use by legal entities in the economy. National accounting standards and international standards are compared. The content of fixed assets and their maintenance in accounting are disclosed. At the same time, attention is paid to the afficient use of fixed assets.

\section{KEYWORDS}

ISA-International standards on Audit, NSA-National Standards on Audit, digital economy, information and communication technologies, communication models, fixed assets, efficiency.

\section{INTRODUCTION}

In the Year of Science, Education and the Development of the Digital Economy, priority is given to the development of the digital economy, the widespread implementation of digital technologies in all spheres of life.
For completeness, it should be noted that the term "digital economy" is a relatively new concept for modern science. For many years, economics has been viewed from a traditional angle perspective, with well-established models of interpersonal relationships and 
procedures. However, the rapid development of information and communication technologies, their penetration into all spheres of life, without exception, has radically changed the model of communication. Thanks to the rapid development of the digital economy, it is now possible to perform all the necessary business operations and document flow remotely with high efficiency. And it's already happening cheaper and faster at this stage. One of the key policy documents defining the vector of development of the digital economy in the industry in the near future is the Resolution of the President of the Republic of Uzbekistan "On measures for the widespread introduction of digital economy and e-government." According to him, by 2023 it is planned to double the share of the digital economy in the country's GDP and triple the volume of services in this area, bringing their exports to $\$ 100$ million. Accordingly, it is planned to implement 268 projects in various areas of economic and economic activity in 2020-2022.

It is an important fact that in the digital environment, the volume of data transmission is growing rapidly from year to year, and more software and hardware are required to process it. Therefore, one of the important tasks of further development of the telecommunications market is also to increase the hardware and server capacity for storing virtual information. Based on this, it is planned to increase the capacity and number of data centers by 10 times compared to current indicators. It is obvious that all enterprises and organizations in our country need to radically improve their equipment, which is their main tool.
The head of state noted that now, during the COVID-19 pandemic, the importance of measures for the wider introduction of digital technologies in public administration, public services, trade, education and other areas has become clear.

\section{METHODS}

Methods of comparison, scientific abstraction, logical thinking, observation and analysis were used in the research process.

\section{RESULTS AND DISCUSSION}

The Software and Information Technology Park (IT-Park) has also adapted its operations and successfully converted its projects to online format. Among the important IT projects implemented during this period are:

- Development of the Telegram bot (Help COVID-19 bot) for advice on COVID-19 infection;

- Introduction of a new public service "Applicant" on the Single portal for online registration of applicants;

- mobile application for self-security to maintain social distance;

- Free Uzbek language courses with Cousera - one of the world's leading online education platforms.

In addition, in quarantine mode, all telecommunications operators and providers offered their subscribers new, more affordable tariffs and new services in order to create additional convenience for their customers.

The fixed asset represents the reproducible means of production: the labor skills of the workers are reproduced using material 
resources. In addition, in our opinion, the fixed assets can include not only the means of labor, buildings and structures, but also the labor of workers.

The result of the enterprise and its level depends on what tools are used, in what condition and at what level of technical development. Generally, fixed assets are considered to be a share of all means of production, ie. means of labor in which a person can influence the object of labor through the process of production, changing it for a specific purpose. The difference between the means of labor and the object of labor is, first of all, that they are repeatedly involved in the production process while preserving their natural and material forms, becoming obsolete and transferring their share value to the product produced. ${ }^{1}$
Fixed assets are used to perform various tasks in the enterprise. Their income and expenses are important for accounting. The income of fixed assets can vary, and the main of them is the purchase. The purchase of fixed assets can be done to ensure safety or to protect the environment. Although the acquisition of such items does not directly increase future economic benefits from the use of existing property, plant and equipment, the future economic benefits to the entity as a result of the use of other assets it may be necessary to take. Such property, plant and equipment meet the requirements for recognition of assets because they provide an opportunity to obtain future economic benefits from the assets associated with the enterprise, rather than the profit to be received if such items are not acquired.

The differences between international and national standards in Uzbekistan. A class of property, plant and equipment is a group of property, plant and equipment that are similar in terms of their nature and use in the activities of an enterprise. The following are examples of individual asset classes:

\begin{tabular}{|c|c|}
\hline International accounting standards (IAS № 16) & National standards of accounting (NSA № 5) \\
\hline 1. land plots; & buildings \\
\hline 1. land and buildings; & machinery and equipment \\
\hline 1. machinery and equipment; & \\
\hline 1. watercraft; & \\
\hline
\end{tabular}

${ }^{1}$ Ortikniyozovich, F. U. (2020). Theme: Forecasts And Results Of The Negative Impact Of The Covid19 (Coronavirus) Pandemic On The World Economy And The Economy Of Uzbekistan. The American
Journal of Interdisciplinary Innovations and Research, 2(08), 108-116. 


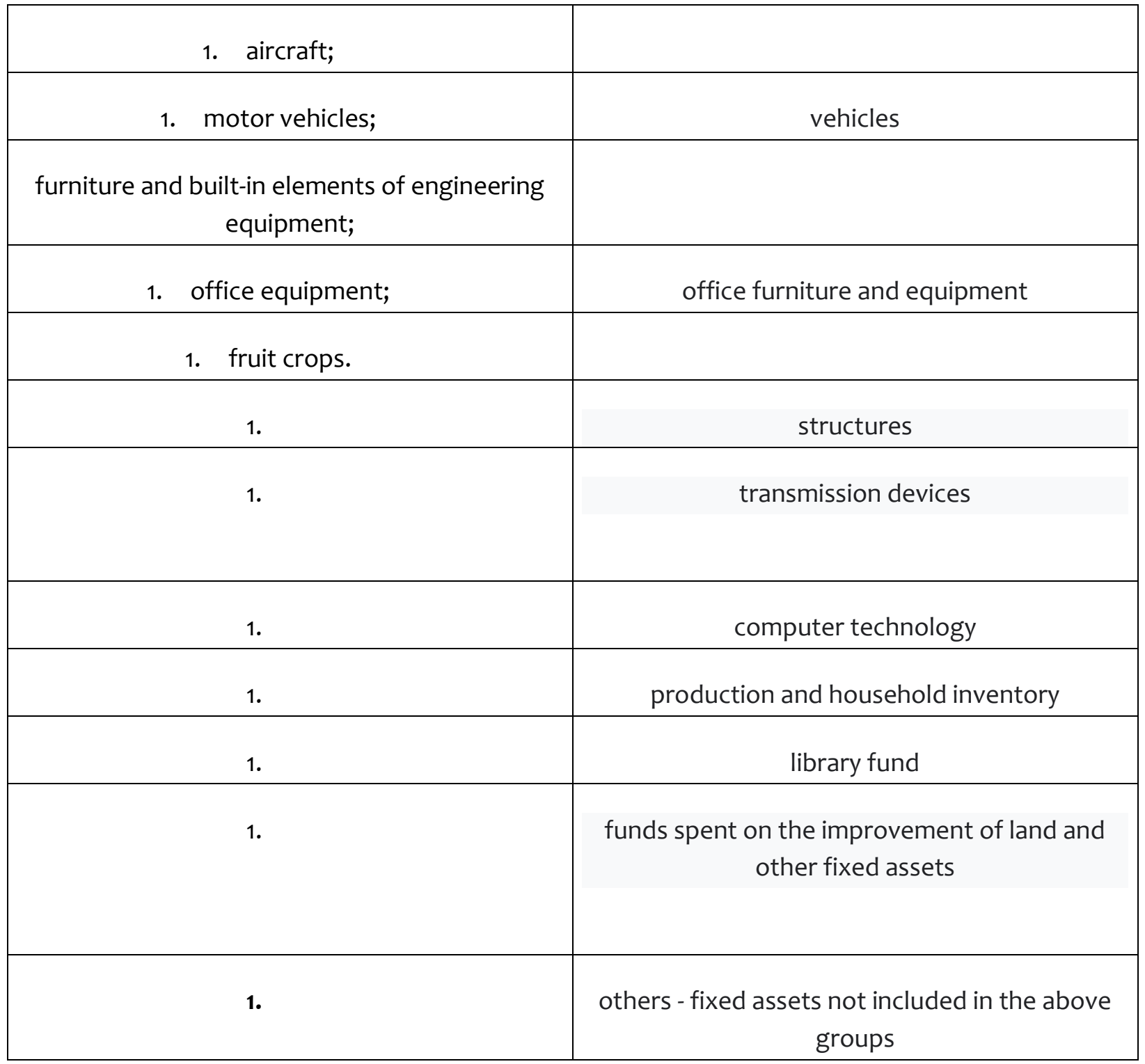

It is clear from the table that our national standards are incomplete compared to the international standards, even some very significant features are missed. The differences between national and international standards on the audit differ not only in the names or substance of the items, but also in the checking of valuation of assets, liabilities, capital.

\section{CONCLUSION AND RECOMMENDATIONS}

Based on the results of the research, we make the following recommendations to improve the process of accounting for fixed assets and their audit:

- Revaluation of fixed assets in accordance with the established standards, their depreciation; 
- Adherence to the economy in the use and operation of fixed assets and inventory, materials, preparation and preparation of reports on them in the prescribed manner;

- To take additional concrete measures to fully form the internal control system in the society and increase their responsibility;

- The effectiveness of the audit of fixed assets depends on the methods used in it. We recommend the widespread use of the following methods in the audit of fixed assets: documentation, comparison, double entry in the accounts, balance sheet, audit analysis;

- Complete collection of evidence on the indicators on which the determination of fixed assets;

- Not to allow the selective verification of indicators that are the basis for the identification of fixed assets;

- Improving the skills of auditors, taking into account changes in legislation.

From the above facts, it is clear that the digital economy is a comprehensive concept that covers all sectors of the economy and all spheres of life without exception.

\section{REFERENCES}

1. Decree of President of the Uzbekistan dated February 24, 2020 № PP-461, On additional measures to transfer International Financial Reporting Standards.

2. Decree of President of the Uzbekistan dated September 19, 2018 № PP-3946, On measures for further development of audit activities in the Republic of Uzbekistan.

3. Национальные стандарты бухгалтерского учета Республики Узбекистан. Издано в издательскоинформационном центре Национальной Ассоциации бухгалтеров и аудиторов. T.:2012 г.

4. International Business \& Economics Research Journal (2010). IFRS Adoption in the EU, Accounting Harmonization and Markets Efficiency: A Review by Gabriele Guggiola, University of Insubria, Varese, Italy Vol. 9, No. 12.

5. Sevara Babanazarova (2020) "About ensuring a fair approach to the effective organization of the professors and teachers work.", Middle European Scientific Bulletin, 5, pp. 88-91. doi: 10.47494/mesb.2020.5.65.

6. http://www.icar.ru - International Center of Accounting Reforms (ICAR)

7. Ortikniyozovich, FU (2020). Theme: Forecasts And Results Of The Negative Impact Of The Covid-19 (Coronavirus) Pandemic On The World Economy And The Economy of Uzbekistan. The American Journal of Interdisciplinary Innovations and Research, 2 (08), 108-116.

8. http://www.gaap.ru - The information center of theory and practice of financial accounting

9. http://www.iasc.org.uk - International Accounting Standards Committee (IASC)

10. http://www.lex.uz/ - NATIONAL DATABASE OF LEGISLATION UZBEKISTAN (LexUz) 